\title{
COMUNICAÇÃO
}

\section{HTLV-I/II SEROPREVALENCE IN 55 BRAZILIAN PATIENTS WITH IDIOPATHIC UVEITIS}

\author{
Sônia R. Pinheiro, Anna B. Carneiro-Proietti, Maria V. Lima-Martins, \\ Fernando A. Proietti, Alexandre A. Pereira and Fernando Oréfice
}

\begin{abstract}
Human T-cell lymphotropic virus type I has been associated with adult T-cell leukemia and lymphoma, neurological disease (tropical spastic paraparesis or HTLV-I associated myelopathy) and, more recently, uveitis. This virus is highly endemic in some regions of the world, especially in southwest Japan, Caribbean islands, South America and parts of Central Africa ${ }^{1}$. The presence of HTLV-I/II in Brazil varies according to the geographical area, with seroprevalence in healthy blood donors ranging from 0.08 to $1.35 \%$ in studies conducted by the Ministry of Health ${ }^{5}$. In Belo Horizonte, the capital of Minas Gerais State, a seroprevalence of $0.32 \%$ has been observed in eligible blood donors.
\end{abstract}

In Japan, seroprevalence for HTLV-I antibodies among patients with idiopathic uveitis ranges from 35.4 to $44.8 \% \%^{2}$. In Brazil, to our knowledge, there is no data on HTLV-I seroprevalence among individuals with this diagnosis.

From March to September of 1994, we tested 55 patients with idiopathic uveitis for the presence of antibodies to HTLV-I/II by using an ELISA (Ortho Diagnostic Systems, New Jersey, USA). Positive tests were confirmed by Western blot (Cambridge Biotech, Maryland, USA). None of the patients presented clinical or laboratorial evidence of systemic disease related to other uveitis types such as toxoplasmosis, syphilis, tuberculosis, ankylosing spondylitis, sarcoidosis, Behçet's disease or Vogt-Koyanagi-Harada's disease. The patients'age ranged from 9 to 78 years (mean, 36.2, SD, 17.52). Thirty-six $(65.4 \%)$ were females and $19(34.6 \%)$ were males. The distribution of the anatomical types of uveitis

\footnotetext{
Departments of Ophtalmology and Preventive and Social Medicine, Federal University of Minas Gerais, Fundação Hemominas, Belo Horizonte, $M G$.

Address to: $\mathrm{Dr}^{\mathrm{a}}$ Anna B. Carneiro-Proietti. Fundação Hemominas. Al. Ezequiel Dias 321, 30130-110 Belo Horizonte, MG, Brasil.

Recebido para publicação em 22/08/95.
}

were as follows: $28(51.0 \%)$ intermediate, $21(38.2 \%)$ anterior, $3(5.4 \%)$ posterior, 2 (3.6\%) posterior scleritis and $1(1.8 \%)$ diffuse uveitis.

Two (3.6\%) patients (a male and a female, with ages of 19 and 62, respectively) with unilateral anterior uveitis were seropositive for HTLV-I/II. Their major complaint was ocular hyperemia and visual acuity was slightly lower than normal. Both had discrete iritis with less than 20 cells in a field and mild flare in the anterior chamber with fine keratic precipitates. There were no nodules in the iris and in the trabecular meshwork. The vitreous body had only a moderate reaction, with less than 10 cells in a field. The ophthalmoscopy was normal in both cases. Both patients were treated with local corticosteroids and improved in about four weeks.

Compared to data from Japan, we found a relatively low seroprevalence of HTLV-I/II antibodies in patients with idiopathic uveitis in Belo Horizonte. However, it was about ten times higher than that of eligible blood donors from the same area. In our patients, the clinical presentation differred considerably from other reports, where intermediate uveitis ${ }^{2}$ or anterior granulomatous uveitis ${ }^{3}$ were more common.

Although limited to selected sites and sample, these results suggest a different epidemiological pattern of HTLV-I/II infection in this geographical region, which needs to be confirmed by further studies.

\section{REFERENCES}

1. Blattner WA, Blayney DW, Robert-Guroff M, Sarngadharan MG, Kalyanaraman VS, Sarin PS, Jaffe ES, Gallo RC. Epidemiology of human T-cell leukemia/lymphoma virus. Journal of Infectious Diseases 147:406-416, 1983.

2. Mochizuki $M$, Watanabe $T$, Yamaguchi $K$, Yoshimura K, Nakashima S, Shirao M, Araki S, Takatsuki K, Mori S, Miyata N. Uveitis associated 
with human T-cell lymphotropic virus type I. American Journal of Ophtalmology 114:123-129, 1992.

3. Nakao D, Matsumoto M, Ohba N. Seroprevalence of antibodies to HTLV-I in patientes with ocular disorders. British Journal of Ophtalmology 75:76$81,1991$.

4. Proietti FA, Lima-Martins MVC, Passos VMA, Brener S, Carneiro-Proietti ABF. HTLV-I/II seropositivity among eligible blood donors from Minas Gerais State, Brazil. Vox Sanguinis 67:77, 1994.

5. Sereno A, Galvão B, Proietti F, Rodrigues L, Franco L, Santana A, Loures L. HTLV-I/II differential geographical distribution in Brazil. Tenth International Conference on AIDS. Japan 2:304,1994. 